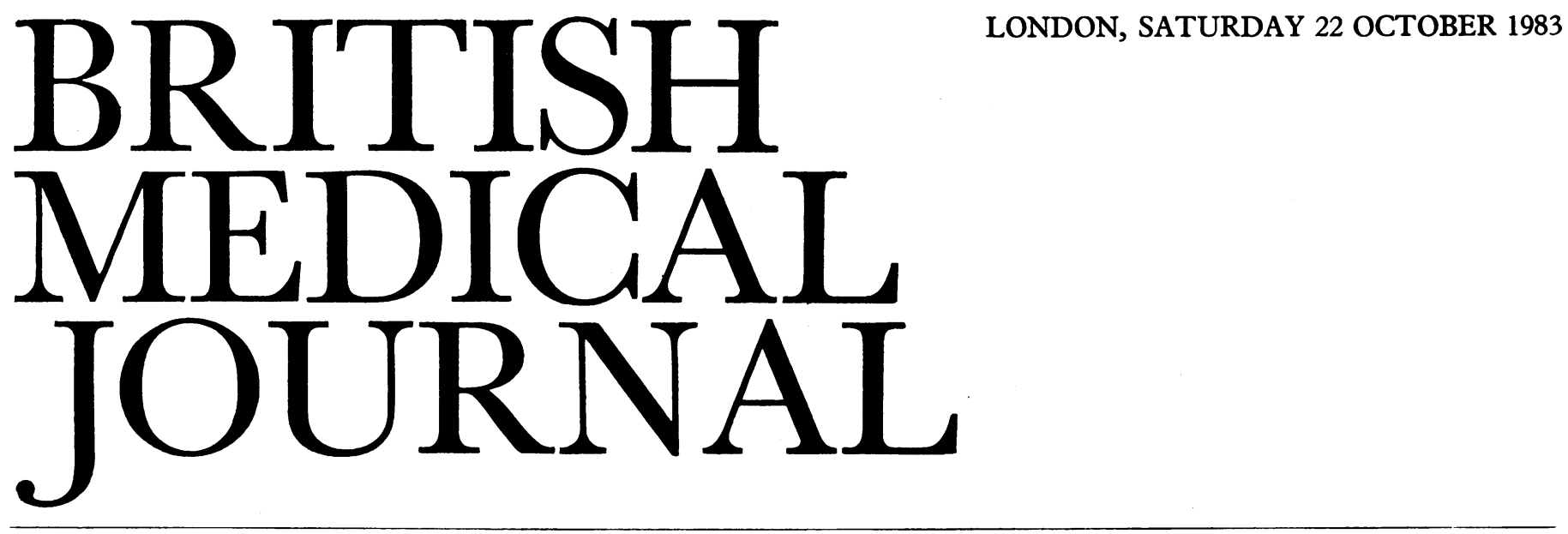

\title{
Why don't the British treat more patients with kidney failure?
}

The management of end stage renal failure in Britain is out of step with practice in other major Western European countries, North America, and Australasia because it excludes older people and diabetics from treatment by dialysis and transplantation. The $B M 7$ has recently published a report from Guy's Hospital on the successful treatment of patients aged over $65^{1}$ and this week carries a report arguing the case "Why blind diabetics with renal failure should be offered treatment," which was written by a British physician now working in the United States ( $p$ 1177). It is thus an opportune time to reexamine our practice.

Contrary to the views of one leader writer, ${ }^{2}$ there are no special British rules about which patients with end stage renal failure may or may not be treated. Nevertheless, limited facilities for treatment have made it necessary for British physicians to practise selection ${ }^{3}$ to a degree which seems strange, even barbaric, to our colleagues in other civilised countries. ${ }^{2}$ We have only $1 \cdot 1$ dialysis and transplant centres per million of the population, in contrast to comparable figures of 5.9 in Italy, 4.4 in the Federal Republic of Germany, 4.3 in Spain, and 3.7 in France. Even Eastern European countries have more centres-3.0 in Yugoslavia and 2.8 in the German Democratic Republic. ${ }^{4}$ It is likely that Britain has fewer doctors and nurses practising nephrology per million population than any of the above countries. ${ }^{5}$ Nor is there any doubt that on average we treat the most patients per centre, compelled as we are to depend on home dialysis, transplantation, and continuous ambulatory peritoneal dialysis as outlets from limited hospital haemodialysis units. "Rationing" has resulted in a highly cost effective national programme for the treatment of end stage renal failure. But is it humane?

In 1981 Scotland accepted 28.7 new patients per million population for treatment and England $25 \cdot 4 .{ }^{6}$ The chance of being offered treatment was higher than this in 16 European countries and the acceptance rate exceeded 40 per million population in the Federal Republic of Germany, France, and Italy.

As the numbers of new patients in different countries have increased the proportion of older patients has grown. In 1971 the ratio of new patients who were over 50 years old to those under 50 was less than 0.3 in all large European countries. Ten years later it exceeded 1.2 in the Federal Republic of Germany, France, and Italy, and was about 0.9 in the Netherlands and Spain; but in Britain it was less than 0.6-smaller than in Yugoslavia, and only a little greater than in the German Democratic Republic. ${ }^{6}$ In 1982 in Britain only 8\% of new patients were aged over 65, whereas in the Federal Republic of Germany the proportion was $24 \%$, in France $25 \%$, in Italy $26 \%$, and in Spain $13 \%$.

What are the chances for the diabetic? The proportion of new patients in 1981 who were diabetic was high in Scandinavian countries (although not reaching the $25 \%$ and more reported from some parts of the United States) and averaged $7 \cdot 3 \%$ for the total European Dialysis and Transplant Association registry. In Britain, 80 diabetics with end stage renal failure accounted for $5.5 \%$ of the total 1981 intake, a crude acceptance rate of 1.4 per million population. This figure was exceeded by 15 other countries on the registry. ${ }^{7}$ In Britain each year at least 500 diabetics develop renal failure, ${ }^{8}$ which means that under $16 \%$ were treated.

Regional services for the treatment of end stage renal failure vary, as they do in the United States. ${ }^{9}$ Crude acceptance rates in 1981 varied from 14.2 to 30.7 per million population in regions whose figures are not thought to be distorted by a flow of patients across boundaries. ${ }^{6}$ For patients over 65 crude acceptance rates varied from 0.3 per million population to 6.3 , and for diabetics from $0 \cdot 7$ to $6 \cdot 8$. Not long ago blind diabetics in the Midlands were among those excluded from treatment, ${ }^{3}$ and a wider inquiry of British renal physicians conducted by Parsons and Lock ${ }^{10}$ showed that 16 out of 23 units would reject a blind diabetic.

Whatever the attitudes of the renal units towards high risk patients and those with handicaps other than their renal failure, it seems likely that many patients are not even referred for assessment, let alone treatment. "Negative selection" by doctors with no recent experience of nephrological practice was highlighted by the recent Yorkshire Television programme "A Lottery for Life." 11 The editor of the New Socialist regards "negative selection" as a "medical euphemism for murder by neglect." 12 Up till now centres have been shielded from the full 
impact of seeing all those patients who are potentially treatable, but things may change. Selection policies will be scrutinised more closely in the future by an increasingly aware public who may demand that the door of our exclusive units is opened wider.

Blind diabetics may be treated by continuous ambulatory peritoneal dialysis ( $\mathrm{p}$ 1177), but unfortunately the staff with the necessary skills are already fully stretched. There is going to be a heavy demand for more facilities, starting with the establishment of more specialist posts in nephrology to double the number of dialysis and transplant centres in Britain. Professor J S Cameron has estimated that it will cost a further $£, 50$ million a year to treat those 2000 people who are at present discarded annually. This is less than we now spend each month on fewer people in the Falkland Islands. ${ }^{12}$

Clearly resources available for health care are finite, and renal physicians and transplant surgeons know (from experience at regional and district levels) that competing demands are virtually infinite. They have thus been constrained to increase to the utmost the cost effectiveness of treatment for end stage renal failure. The inception of the services for renal failure in Britain 10 years ago required earmarked central funding. What hope is there that this might be repeated in the present economic climate? Many are gloomy, but it was encouraging that Lord Glenarthur, at the start of his tenure of office as Joint Parliamentary Under Secretary of State at the Department of Health and Social Security, opened the recent congress of the European Dialysis and Transplant Association by referring to the pooled information provided by the association as "an incentive to those countries that lag behind others in the various aspects of service provision," and concluded, "because there is an unmet need, there is a duty on us to increase the quantity of provision." Despite the fact that the congress was an occasion for the expression of aspirations rather than policy, and that Lord Glenarthur's speech included an inevitable caveat about constraints on resources, we hope that new administrative routes will be found to translate central initiative and political goodwill into improved regional services for patients with end stage renal failure.

A J WING

Consultant Physician,

St Thomas's Hospital,

London SE1 $7 \mathrm{EH}$; and

Chairman,

European Dialysis and Transplant Association Registration Committee

Taube DH, Winder EA, Ogg CS, et al. Successful treatment of middle aged and elderly patients with end stage renal disease. $\mathrm{Br}$ Med $\mathcal{F} 1983$; $\mathbf{2 8 6}: 2018-20$.

Berlyne GM. Over 50 and uraemic $=$ death. Nephron $1982 ; 31: 189-90$

3 Royal College of Physicians' Medical Services Study Group. Deaths from chronic renal failure under the age of $50 . \mathrm{Br}$ Med $71981 ; \mathbf{2 8 3}: 283-6$.

${ }^{4}$ Kramer P, Broyer M, Brunner FP, et al. Combined report on regular dialysis and transplantation in Europe, XII, 1981. Proc Eur Dial Transplant Assoc 1982;19:2-91.

${ }^{5}$ Renal Association, Executive Committee. Report. Distribution of nephrological services for adults in Great Britain. Br Med f 1976;ii:903-6.

${ }^{6} \mathrm{Wing} \mathrm{AJ}$, Broyer $\mathrm{M}$, Brunner FP, et al. EDTA registry analyses. In: Bradley B, Moras D, eds. UK Transplant Service review 1982. Bristol: UK Transplant Service, 1982:33-64.

${ }^{7}$ Jacobs C, Brunner FP, Brynger H, et al. The first five thousand diabetics treated by dialysis and transplantation in Europe. Diabetic Nephropathy $1983 ; 2: 12-6$.

${ }^{*}$ Cameron JS. The management of diabetic renal failure in the United Kingdom. [Editorial.] Diabetic Nephropathy 1983;2:1-2.

${ }^{9}$ Relman AS, Rennie D. Treatment of end-stage renal disease: free but not equal. [Editorial.] N Engl f Med 1980;303:996-8.

${ }^{10}$ Parsons V, Lock P. Triage and the patient in renal failure. $\mathcal{f}$ Med Ethics $1980 ; 6: 173-6$.

11 Wing AJ. Medicine and the media. Br Med f 1983;287:492.

12 Curren J. White coats and black cap. The Times 1983 Aug 10:8 (col 6).
The consultant rheumatologist and postgraduate education

Rheumatic diseases form one of the greatest burdens of morbidity in the community, ${ }^{12}$ accounting for nearly a quarter of all general practitioner consultations and a 10th of all new diseases seen in general practice. ${ }^{34}$ After fractures and neoplasms they are the third most common cause of referral to hospital outpatient departments. In one teaching hospital they accounted for one in three of all general medical follow up visits and one in four of all new patients in the general medical clinic.

If more of these patients could be managed in general practice the burden would be lessened for hospital staffs; while many patients would be pleased not to have to attend the hospital. ${ }^{\overline{1}}$ The way forward may lie in improved undergraduate education in rheumatolcgy-an excellent model for the teaching objectives of enhanced knowledge, improved attitudes, and better skills. ${ }^{6}$ Most doctors acknowledge these needs $^{7}$ but there are limits to what can be taught in an overcrowded curriculum.

It might be argued that the purpose of undergraduate education is to produce a healthy stem cell which can differentiate later. Unfortunately the differentiation seldom occurs along the line of rheumatology. A survey of 600 medical practitioners showed that it ranked 18th in the order of medical specialties in which postgraduate instruction had been received, only $19^{\circ}$ o having attended such a course. ${ }^{7}$ Moreover, at such courses the content often bears little relation to the problems encountered in general practice. ${ }^{8}$ In a survey of 186 general practitioners, $M$ Thompson (personal communication, 1983) found that the conditions on which they most wanted teaching were backache, clinical topics, and drug treatment. Those in which instruction was least wanted were medical social work, manipulation, and surgery. He also found that general practitioners wanted instruction from the local consultant rather than from visiting consultants, fellow general practitioners, or paramedical staff.

How, then, should such instruction be given? The matter was discussed in detail at a recent symposium organised by the Arthritis and Rheumatism Council under the chairmanship of Professors G Nuki and T Maini. Badley and Wood had surveyed the postgraduate teaching practices of consultant rheumatologists in Britain, finding that the lecture was used most often-and least appreciated by the audiences. Other methods have been explored. The Royal College of General Practitioners has set up experimental courses designed to meet the needs identified from analysis of general practitioner referrals to hospital. Possible deficiencies of care were compared with the treatments given by general practitioners with rheumatic experience. ${ }^{9}$ Courses of this kind can halve referrals to hospital and increase the range of treatments given in general practice. ${ }^{8}$

$R$ Grahame has developed an educational package made up of a course on the precise diagnosis of common soft tissue lesions, including demonstrations of examination and instruction in techniques for injecting steroids, the use and abuse of antirheumatic drugs, and the best use of physiotherapy and occupational therapy in rheumatic disorders. Instruction was given at general practitioner surgeries, and the preliminary results are encouraging. Working in a district general hospital, D I Haslock emphasised education in the proper use of 